\title{
Avaliação do potencial cicatrizante do ácido carnósico e do ácido rosmarínico presente no extrato do Rosmarinus officinalis -Alecrim.
}

\author{
Lucas Militão*, Janaína A. Ataide, Letícia C. Cefali, Marcelo Lancellotti, Priscila G. Mazzola.
}

\section{Resumo}

O alecrim, uma planta usada popularmente, contém compostos bioativos com notada capacidade antioxidante, como o ácido carnósico e o ácido rosmarínico. Quatro métodos de extração foram avaliados quanto à eficiência na extração dos compostos antioxidantes e sua ação no ensaio de cicatrização scratch. Dentre os métodos utilizados, a maceração se mostrou a mais eficiente na extração dos compostos antioxidantes. Os extratos apresentaram atividade antioxidante e não apresentaram citotoxicidade significativa, porém o extrato obtido pelo método maceração, testado no cicatrização in vitro, não acelerou o processo de cicatrização nas condições testadas.

\section{Palavras-chave:}

Alecrim, Cicatrização, Compostos bioativos.

\section{Introdução}

Rosmarinus officinalis popularmente conhecido como alecrim é uma planta aromática, da família das Lamiaceae. Diversas propriedades medicinais têm sido atribuídas ao alecrim como: antifúngica, anti-inflamatória, antibacteriana. $O$ alecrim também se destaca pela sua propriedade antioxidante atribuída principalmente aos compostos ácido carnósico, carnosol, e ácido rosmarínico ${ }^{1}$. Os radicais livres, formados durante o processo de cicatrização, tem efeitos fisiológicos, no entanto, quando o nível de radicais livres se torna alto, ocorre danos às células e tecidos vizinhos à ferida ${ }^{2}$. $O$ presente trabalho teve como objetivo investigar o efeito cicatrizante dos compostos bioativos presentes no extrato de alecrim.

\section{Resultados e Discussão}

Quatro métodos foram empregados para extração dos compostos bioativos presentes no alecrim: maceração, infusão, ultrassom e soxhlet. Para a extração foram utilizadas $5 \mathrm{~g}$ de planta seca para $100 \mathrm{~mL}$ de solvente (60/40) de etanol/água. O método DPPH foi utilizado para avaliação da capacidade antioxidante.

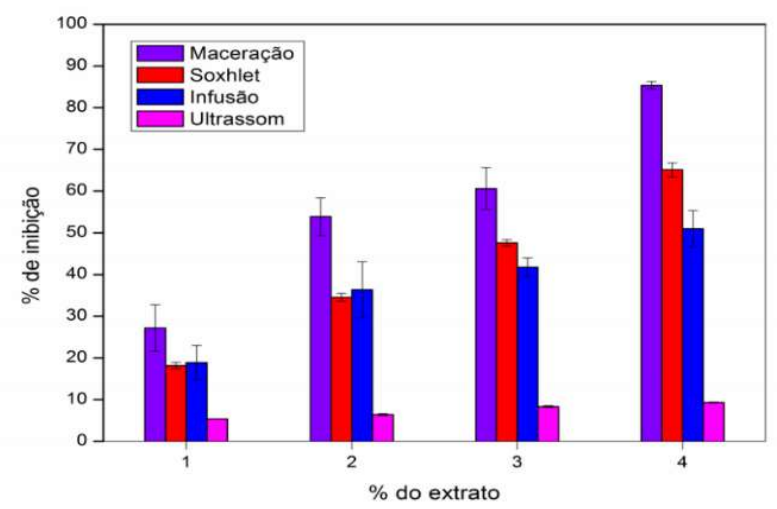

Figura 1. porcentagem de inibição dos radicais DPPH pelos extratos em diferentes concentrações.

O método maceração mostrou-se superior quanto à extração de compostos antioxidantes, pois $4 \%$ de extrato foi capaz de inibir $85,3 \%+/-0,9$ dos radicais $\mathrm{DPPH}$, enquanto e o método ultrassom foi o que apresentou a porcentagem mais baixa de inibição, atingindo inibição máxima de 9,3\% +/- 0,1 dos radicais na mesma concentração. A viabilidade celular foi determinada através do ensaio colorimétrico MTT utilizando-se células HaCat. Em concentrações iguais ou inferiores a 1,5\% do extrato, não houve impacto na viabilidade celular, pois nessas condições a viabilidade celular ficou acima de $50 \%$ para todos os extratos após $24 \mathrm{~h}$ e $48 \mathrm{~h}$. O extrato obtido pelo método maceração foi escolhido para o ensaio de cicatrização in vitro em células HaCat devido ao seu maior potencial antioxidante. As concentrações testadas foram 1, 2 e $4 \%$. Nessas condições, o extrato não acelerou a cicatrização em comparação ao controle.

\section{Conclusão}

O potencial antioxidante difere dependendo do método empregado, ou seja, cada método extrai os compostos bioativos com diferentes eficiências. Supõe-se, portanto, que o método maceração foi o que mostrou maior potencial para extração desses compostos antioxidantes. Os extratos acima foram avaliados pelo seu impacto na viabilidade celular e nenhum se mostrou citotóxico em concentrações inferiores a $1,5 \%$. O extrato obtido pelo método maceração não acelerou $o$ processo de cicatrização in vitro em nenhuma das concentrações testadas. No entanto, dados da literatura corroboram para a utilização de compostos antioxidantes na cicatrização ${ }^{3}$.

\section{Agradecimentos}

Agradecimentos ao Laboratório de Farmacotécnica e Farmácia Clínica da Unicamp, à orientadora Profa. Dra. Priscila Gava Mazzola, às suas alunas de doutorado Letícia Caramori Cefali e Janaína Artem Ataíde, ao CNPQ, Capes e FAPESP e ao Professor Dr. Marcelo Lancellotti.

\footnotetext{
${ }^{1}$ Houghton, P. J.; Hylands, P. J.; Mensah, A. Y.; Hensel, A.; Deters, A. M. Journal of Ethnopharmacology, v. 100,n. 1-2, p. 100-107, 2005.

${ }^{2}$ Jorge, N.; Ramalho, V. C. . Revista do Instituto Adolfo Lutz, v. 65, n. 1, p. 15$20,2006$.
}

${ }^{3}$ Hyun, H. B.; Shrestha, S.; Boo, K. H.; Cho, S. K. . Journal of the Korean Society for Applied Biological Chemistry, v. 58, n. 5, p. 715-722, 2015. 